3. Grgic A, Rosenbloom AL, Weber FT, Giordano B, Malone JI, Shuster JJ (1976) Joint contracture - Common manifestation of childhood diabetes mellitus. J Pediatr 8: 584-588

4. Buckingham BA, Uitto J, Sandborg C, Kens T, Roew T, Costin G, Kaufman F, Bernstein B, Landing V, Castellano A (1984) Scleroderma-like changes in insulin-dependent diabetes mellitus: clinical and biochemical studies. Diabetes Care 7: 163-169

5. Kennedy L, Richie C, Lyons TJ, Beacom R (1986) Limited joint mobility in diabetes - some clinical and biochemical aspects. In: Serrano-Rios M, Lefevre PJ (eds) Diabetes 1985. Elsevier, Amsterdam, pp 767-770

6. Monnier VM, Vishwanath V, Frank KE, Elmets CA, Dauchot P, Kohn RR (1986) Relation between complications of type I diabetes mellitus and collagen-linked fluorescence. N Engl J Med 314: 403-408

7. Lawson PM, Maneschi F, Kohner EM (1983) The relationship of hand abnormalities to diabetes and diabetic retinopathy. Diabetes Care 6: 140-143

8. Rosenbloom AL, Silverstein JH, Lezotte DC, Richardson K, McCallum M (1981) Limited joint mobility in childhood diabetes mellitus indicates increased risk for microvascular disease. N Engl J Med 305: 191-194

9. Buckingham B, Perejda AJ, Sandborg C, Kershnar AK, Uitto J (1986) Skin, joint, and pulmonary changes in type I diabetes mellitus. Am J Dis Child 140: 420-423

10. Seibold J (1982) Digital sclerosis in children with insulin dependent diabetes mellitus. Arthritis Rheum 25:1357-1361

11. Kennedy L, Beacom R, Archer DB, Carson DJ, Campbell SL, Johnston PB, Maguire CJ (1982) Limited joint mobility in type I diabetes mellitus. Postgrad Med J 58: 481-484
12. Starkman HS, Gleason RE, Rand LI, Miller DE, Soeldner JS (1986) Limited joint mobility (LJM) of the hand in patients with diabetes mellitus: relation to chronic complications. Ann Rheum Dis $45: 130-135$

13. Madacsy L, Peja M, Korompay K, Biro B (1986) Limited joint mobility in diabetic children: A risk factor of diabetic complications? Acta Paediatr Hungarica 27:91-96

14. Costello PB, Tambar PK, Green FA (1984) The prevalence and possible prognostic importance of arthropathy in childhood diabetes. J Rheumatol 11: 62-65

15. Mengistu M, Abdulkadir J (1985) Limited finger joint mobility in insulin-dependent and non-insulin-dependent Ethiopian diabetics. Diabetic Med 2: 387-389

16. Fitzcharles MA, Duby S, Waddell RW, Banks E, Karsh J (1984) Limitation of joint mobility (cheiroarthropathy) in adult non-insulin-dependent diabetic patients. Ann Rheum Dis 43: 251-257

17. Larkin JG, Frier BM (1986) Limited joint mobility and dupuytren contracture in diabetic, hypertensive, and normal populations. $\mathrm{Br}$ Med J 292: 1494

\section{Dr. L. Rosenbloom}

Division of Endocrinology

Department of Paediatrics

College of Medicine

University of Florida

Box f-296

f. Hills Miller Health Center

Gainsville, Florida 32610

USA

\title{
The skin in diabetes mellitus
}

Dear Sir,

We are grateful for the opportunity to reply to the letter from Dr. Rosenbloom. Our brief discussion of "thick skin and limited joint mobility [1]: cheiroarthropathy" was included under this rubric (and not simply as cheiroarthropathy) because the main point of discussion was the skin, with reference to the joints only as an association. Clinically obvious cutaneous changes due to thick skin occur principally in an acral distribution [2], and it was to this we addressed ourselves. The term cheiroarthropathy is well recognised, and correct, for the limited form of cutaneous involvement with stiffness of small joints that we, as dermatologists, recognise most commonly. We did not suggest that limitation of joint movement is caused solely by skin thickening, simply that they are closely associated; there is clearly thickening of other soft tissues that may be relevant.

The histological changes described in the skin of patients with diabetes are widespread [3] and are not limited to areas of clinical abnormality, where the changes are different only quantitatively. In our discussion of the general effects of diabetes on the skin, we drew attention to this and to the relationship of skin thickening to vascular abnormalities and aging, particularly to relative cutaneous ischaemia. Postural and gravitational features serve to localise vascular abnormalities, not just in diabetes, but also in systemic sclerosis [4], lipodermatosclerosis [5], and the vasculitic syndromes [6]. In the first two instances, where the microvascular disorder is chronic, ischaemia is associated with cutaneous sclerosis, and the histological appearances are very similar to those seen in diabetic thick skin. In addition, the striking relationship of thick skin (and Dr. Rosenbloom's LJM) to other microvascular complications of diabetes leads us to propose that the microvasculature holds the key to the cutaneous pathology, as it does to retinopathy, nephropathy and neuropathy.

Dr. Rosenbloom concedes that there is a lack of relationship between collagen glycosylation and LJM, and presumably to thick skin. The statistical relationship described by Monnier [7] showed a correlation coefficient $(r)$ between joint stiffness and skin collagen fluorescence of 0.34 . This may have struggled to significant levels, but the measure of dependance of one variable on the other $\left(r^{2}\right)$, of 0.12 , indicates that we must look elsewhere for causative association. If we were to accept the correlation, we would have to assume that it is skin collagen glycosylation that determines joint stiffness, since there is little evidence that glycosylation of other connective tissue is related directly or otherwise to that in the skin. We have not stated that the skin is the cause of the joint problem, and Dr. Rosenbloom is in error in assuming that we believe it to be so.

Dr. Rosenbloom raises an important point in the discussion of the interpretation of LJM. Our intention was to stress the dangers of generalisation of an observation to groups other than those in whom the original observation was made. The detection of LJM may possibly be of significance in a group of young diabetics with multiple complications of their disease but is of little specificity in the patients who make up the majority of those seen in clinical practice, i.e. the older diabetic, where age related changes in the vasculature and connective tissue confound the issue.

We accept that skin collagen glycosylation correlates with $\mathrm{HbA}_{1}$ levels. If control is poor, and the duration of hyperglycaemia longer, it is self-evident that there is greater opportunity for the early step in 
non-enzymatic browning to progress to form irreversible fluorescent end products. Accepting that these are responsible for the development of thick skin, it is inevitable that there will be a durational effect on skin thickness, and indeed, there is evidence for this [7, 8]. Dr. Rosenbloom does not make clear how he interprets the relationship between these skin changes and the other complications of diabetes. We believe the skin changes to be representative of a common pathological mechanism, produced by the microvascular disorder, ultimately related to the hyerpglycaemic state. Non-enzymatic glycosylation occurs more rapidly and earlier in diabetics but is a feature of aging tissue. Similar cutaneous changes occur in elderly populations their occurence in diabetes represents an accelerated but not unique process.

Yours sincerely,

M.J.D. Goodfield

\section{References}

1. Goodfield MJD, Millard LG (1988) The skin in diabetes mellitus. Diabetologia 31: $567-575$

2. Rosenbloom AL, Silverstein JH, Lezotte DC, Richardson K, McCallum M (1981) Limited joint mobility in childhood diabetes mellitus indicates increased risk of microvascular disease. N Engl J Med 305: 191-194
3. Braverman IM, Yen AK (1984) Ultrastructural abnormalities of the microvasculature and elastic fibres in the skin of juvenile diabetics. J Invest Dermatol 12: 270-274

4. Rowell NR (1984) Systemic sclerosis. The Watson-Smith Lecture. J Roy Col Phys Lond 19: 23-30

5. Browse NL (1983) Venous ulceration. Br Med J 286: 1920-2002

6. Ryan TJ, Wilkinson DS (1986) Cutaneous Vasculitis: "Angiitis". In: Rook A, Wilkinson DS, Ebling FJG, Champion RH, Burton JL (eds) Textbook of dermatology. Blackwell, Oxford, pp 1121-1138

7. Monnier VM, Vishwanath V, Frank KE, Elmets CA, Dauchot $P$, Kohn RR (1986) Relationship between complications of Type I diabetes mellitus and collagen linked fluorescence. $N$ Engl J Med 314: 403-407

8. Collier A, Matthews DM, Kellet HA, Clarke BF, Hunter JA (1986) Change in skin thickness associated with cheiroarthropathy in Insulin dependent diabetes mellitus. Br Med J 292: 936

Dr. M.J. D. Goodfield

The General Infirmary at Leeds

Great George Street

Leeds LS1 3EX

UK 